\title{
Institutional Repositories In University Libraries In Nigeria And The Challenge Of Copyright
}

\author{
Okoroma Francisca N. \\ Kenneth Dike Library \\ University of Ibadan, Nigeria \\ Abioye A. A. \\ Department of Library \\ Archival and Information Studies, \\ University of Ibadan, Nigeria
}

\begin{abstract}
Copyright is a focal issue contending with the development of institutional repositories (IRs). Extant literature focused on the awareness, benefits and the various IR activities across the globe. This study investigated the issues of copyright in institutional repository in universities' libraries in Nigeria. The study adopted the descriptive survey research design. A multistage sampling procedure was employed to sample 844 lecturers of the universities in Nigeria. Data generated were analyzed using descriptive statistics. The findings revealed that plagiarism, piracy, counterfeiting, photocopying and lack of non workable policy guiding copyright matters and its implementations are among the copy right issues hindering the deployment and sustenance of institutional repositories in Nigeria. The study advocated for adequate legal framework and a workable policy guiding copyright matters.
\end{abstract}

Keywords: Institutional repositories, universities, libraries, Copyright and Nigeria

\section{INTRODUCTION}

Universities are the major centre for research output and other valuable literature. However, many of the literature remain unpublished and are never utilised by the masses. There is a glaring divide between the explosive output of literature in the universities and the users of information for education, research and manpower development. Institutional repository becomes imperative to maximise the visibility and global impact of the institution's intellectual outputs, and also considering the weakness of the existing model of publishing which is rigorous, time consuming, expensive, and scarcely caters for the grey materials and other local scholarship. In the light of the innumerable benefits of institutional repository, university libraries all over the world are resorting to institutional repository as a means of coping with, preserving and disseminating (for full impact) the ever increasing scholarly output of universities. Literature has revealed insignificant adoption rate of institutional repository in Nigeria. Out of 3,370 institutional repositories in the world, Africa has only 95 (3.7\%) repositories and Nigeria has just 8 (7.9\%) out of 95 repositories in Africa (OpenDOAR, 2014). This dismal record of IRs in Nigeria can be attributed to the various factors associated with the sustenance of institutional repositories. Prominent amongst the factors of IR is the issue of copyright especially in the developing countries.

Copyright issue has exerted so much conflict in IR content recruitment. Though content recruitment is a fundamental aspect of IR (there cannot be IR if the content is not there in the first place), yet a survey of ARL libraries identified content recruitment as the number one 
challenge in the implementation of an IR (Bailey, 2006). Earlier studies consistently reported that recruiting content is difficult (Ware 2004; Rowlands and Nicholas 2005; Lynch and Lippincott 2005; Heery and Anderson 2005; Ware 2006; Davis and Connolly 2007; Salo 2008). Harnad (2009) indicated difficulties in populating IRs and disciplinary repositories through voluntary submissions have led to proselytising for mandates. Salo (2008) in over viewing the state of institutional repositories, painted an abysmal picture of lecturers disinterest in populating institutional repositories. Kim (2010) ascertained that the biggest barrier to selfarchiving is the academics' concern about copyright. Many other studies (Manjunatha and Thandavamoorthy, 2011; Creaser, 2010; Cullen and Chawner, 2010; Abrizah, 2009; Kim, 2008; Kingsley, 2008; Davis and Connolly, 2007; Van-Westrienen and Lynch, 2005) noted that academics are not yet certain of the copyright status of their published works, as a result, they are hesitant to deposit such work in their IRs in order not to violate copyright law. Institutional repositories cannot continue to exist without the unwavering support of the lecturers, hence, the need to look into the copyright related issues in institutional repositories.

\section{THE CONCEPT OF INSTITUTIONAL REPOSITORY}

Institutional repository has been partly linked to the notion of a digital library http://en.wikipedia.org/wiki/Digital_libraryi.e., collecting, housing, classifying, cataloguing, curating, preserving, and providing access to digital content, analogous with the library's conventional function of collecting, housing, classifying, curating, preserving and providing access to analog content. The first examples of IRs were developed in the early 1990s (e.g., arXiv). Since then, the number of IRs has been increasing not only in the United States and Europe but also in other parts of the world (Tonta, 2008). According to Tonta, (2008) institutional repository movement is an outgrowth of two movements that preceded it: Open Archives Initiative (OAI), which designed the OAI Protocol for Metadata Harvesting in order to make all (what eventually came to be called) institutional repositories interoperable and Open Access (OA) movement, which defined the primary target contents of IRs within academic institutions (refereed research journal articles) and the fundamental reason for depositing them (to make research freely accessible to all would-be users online so as to maximize research uptake, usage and impact). An institutional repository concentrates on the institutional product credited by academic or other institutions researchers, making it easier to demonstrate its scientific, social and financial values (Dabholkar, 2008).

The case for institutional repositories was made by SPARC in 2002 where Crow (2002) described institutional repositories as, "digital collections capturing and preserving the intellectual output of a single or multi-university community". That means that Institutional repository has a way of reducing the cost of scholarly publication and increasing visibility and access of scholarly research from faculty and students of academic institutions by hosting them in the institution's professional societies, or third-party provider's website. Crow continued that IRs provide a compelling response to two strategic issues facing academic institutions: they provide a central component in reforming scholarly communication by stimulating innovation in a disaggregated publishing structure; and they serve as tangible indicators of an institutions quality, thus, increasing its visibility, prestige, and public value. An institutional repository can also be defined by the purpose that it serves: in essence, this is the capture, collection, management and dissemination of the 'intellectual output of a single or multiuniversity community'. (Markey et al.)

Pennock, (2007) posited that the range of digital materials created by an institution and its community members is highly diverse. An IR for example, may include pre-prints or postprints of published articles or research reports, conference papers, teaching and e-learning materials, e-theses, primary research data and datasets, electronic records, multimedia, or 
image materials to name but a few. Repositories that contain a mix of these materials are commonly referred to as 'hybrid' repositories. Manjunatha (2011) collaborated that IR may hold various kinds of publications, such as pre-prints and post-prints of journal articles, conference papers, research reports, theses, dissertations, softwares, datasets, videos, audios and other scholarly items. This way, intellectual contributions of scholars are made available free of charge to the whole knowledge community around the world. Institutional Repositories give opportunity to faculties and research scholars from universities to freely publish and facilitate open access to the results of their research activities, especially now that it is obvious that the traditional model of scholarly communication via subscription-based journals serves to hinder rather than expand access to research output. In the light of emerging trends in digital scholarly communication, open access institutional repositories play an important role in the preservation and dissemination of institutional research outputs which in turn becomes a constituent part of a global research output. (Velterop, 2004).

Christian (2008) stated that in the case of research and academic institutions in developing countries, development of institutional repository will not only boost the global visibility and utility of their research, but will also introduce a novel research culture focused on meeting international standard and values. The knowledge by a researcher that his research will be openly accessible by a global audience will have an impact on his focus and standard.

Institutional Repositories provide access to a wealth of scientific and technological information and knowledge which are very essential for development. The opportunities presented by institutional repositories and Open Access archives to the development of Africa as well as the challenges hindering the development of digital information repositories on the continent have been examined by Chisenga (2006). Therefore the establishment of Institutional Repositories in academic and research institutions in Africa is a serious developmental issue that requires urgent attention.

Dabholkar (2008) opined that an institutional repository concentrates on the institutional product credited by academic or other institutions' researchers, making it easier to demonstrate its scientific, social and financial values. The benefit of institutional repositories is that they enable free sharing of information, encouraging collaboration and the widespread communication of institutional education and research activity. Jones, Andrew and MacColl (2006) explained that "The faster the research is known and understood, the faster we all benefited." Hence, Institutional Repository can play effectively communication tool role with the very remarkable speed. When various digital materials, including faculty e-prints, student work and archival primary sources, are put together, digital content has the potential to become the greatest intellectual capital of an institution.

Rieh ( 2007) reported that: "an IR provides access to those collections that no one would ever know exists." Rosenblum (2008) ascertains that an IR is a resource or a system that facilitates the capture, storage, preservation, and dissemination of an institution's intellectual outputs in an electronic form. Such outputs vary from one institution to the other, but often capture theses and dissertations, while others capture published papers, unpublished preprints, working papers, conference presentations, datasets, teaching materials, etc. Most IRs also include other grey literatures which are usually difficult by their nature to access by researchers. IRs therefore complement and boost the library resources and services. Institutional repositories can provide an immediate and valuable component to the existing scholarly model, while stimulating innovation in a new disaggregated publishing structure that will evolve and improve over time. Furthermore, they build on a growing grassroots faculty 
practice of self -posting research online. They facilitate development of university intellectual property policies; and encourage faculty and administration perspective on these issues.

\section{COPYRIGHT ISSUES AND INSTITUTIONAL REPOSITORY}

Copyright and intellectual property issues have been a concern for faculties in the use of IRs. Despite the fact that most publishers allow authors to make their articles accessible via their university's intellectual repository, authors are concerned that they may be violating the copyright agreements they signed with their publishers by depositing their papers into an institutional repository. A study conducted by Foster and Gibbons (2005) interviewed 25 professors at the University of Rochester about why faculty members did not submit their content to the institutional repository, found that copyright infringement worries and disciplinary work practices compel them not to contribute actively to the university's IR.

Copyright refers to the exclusive right granted an author and other creative artists to authorise the use of their works in any way. Copyright, often referred to as specific rights or neighboring right are used by some countries to protect the works of performers, phonogram producers and broadcasters (World Bank Discuss papers, 1990).The concept of copyright was devised for the society for two main purposes; to encourage creative people to produce works of culture and to provide incentives for the effective dissemination of these works. The copyright law is not designed to limit public access to information but to ensure that the public has access to it by protecting the economic and moral rights of the authors thereby enhancing more varied publications (Okwilagwe, 2001). Egonwa (2005) noted that the rate of copyright violation in Nigerian tertiary institutions is quiet dismal. The author identified reprography as the major way in which the various activities amounting to violation or infringement of are realized. This calls for strengthening of copyright management in Nigeria to enhance the participation of academics in the use of IRs. The greater the concerns about publisher permission or the fear of infringing on copyright, the less likely academics are to support IR.

The copyright Act Chapter 68, laws of the Federation of Nigeria 1990 identifies works that will have copyright protection in Section 1 of the Act. They are literary works, Musical Work, Artistic Work, Cinematography Films, sound recording and broadcast. Nigeria had a Copyright Council which was upgraded to the Nigerian Copyright Commission in 1996. The copyright law in Nigeria was administered by the NCC which was a corporate body set up by the Federal Government under the Ministry of Culture and Social Welfare (Okilagwe, 2001). The Council was charged with the responsibility for all copyright matters in Nigeria. These include: Enforcing the copyright law, enlightening and informing the general public on matters relating to copyright, ensuring that those who use works of Nigerian authors pay adequate royalties, representing the interests of all Nigerian artists in international copyright matters and keeping records of all Nigerian authors.

Egonwa (2005) identified that the Reproduction Rights organisation of Nigeria (Repronig) is the only government approved rights management society for the print medium in Nigeria. It began formal operation on 3rd November 2003. It was empowered by law to negotiate, collect and share royalties to relevant stakeholders. Repronig's international relationship with a network of associations established to protect the rights of its members and stakeholders, gives her a robust base to operate at home and abroad. Repronig` membership is actually a coalition of professional associations in the creative arts umbrella such as the Society of Nigerian Artists (SNA), Association of Nigerian Authors (ANA), Newspapers proprietors Association (NPA), Photographers Association of Nigeria (PAN), Nigerian Association of Translators and Interpreters (NATI) and the Academic and Non-Fiction Authors' Association of Nigeria (ANFAAN). Even the Nigerian Union of Journalist (NUJ) and the Nigerian Guild of 
Editors (NGE) are expected to join. The question often asked is, can this fair practice of licensing the exploitation of reprographic material be feasible in Nigeria?

Egonwa (2005) identified a large scale of ignorance on the part of the right owners, the supportive institutions such as the university and the college authorities as well as the guilds or associations of business center owners' accounts for the apparent non-feasibility of the project. The author noted that it is feasible to license users of works protected by rights provided these users are brought to the full knowledge of the moral, legal and spiritual implications of their present activities.

The research conducted by Igbeneghu (1993) on photocopying activities and violation of copyright in seven Nigerian Universities revealed that there were about 173 photocopy establishments and centres in the selected number of Nigerian universities, 81 million sheets of duplicating paper are exposed yearly to photocopying in the seven universities; about 53 million of the exposure involved published materials; and that the Nigerian copyright law is being infringed upon; and that photocopy is injurious to the publishing industry.

Literature has revealed few previous studies on IRs in universities in Nigeria (Christian, 2008; Nwokedi, 2011) and none of the studies have actually addressed the copyright issues affecting the development of institutional repositories in university libraries in Nigeria.

The main objective of the study is to investigate the various copyright related issues hindering institutional repositories in university libraries in Nigeria.

\section{The specific objectives are to:}

- Identify the various copyright issues affecting institutional repositories in university libraries in Nigeria.

- Proffer solutions to the copyright issues hindering institutional repositories in university libraries in Nigeria.

\section{METHODOLOGY}

The study adopted a survey research design. It involved quantitative and qualitative methods of data collection. The study adopted a multistage sampling procedure. The purposive sampling technique was used in the selection of eight institutions that participated in the study. These institutions were Ahmadu Bello University, Covenant University Ota, Ogun State, Federal University of Technology, Ondo State, Obafemi Awolowo University, Osun State, University of Ibadan, Ibadan, Oyo State, University of Jos, Plateau State, University of Nigeria, Nsukka, Enugu State and the Federal University, Oye Ekiti, Ekiti State. These institutions were purposively selected because they were the only universities adopting institutional repository in Nigeria. The study further adopted the purposive sampling technique to sample three (3) faculties of the institutions. These faculties were the faculties of sciences, social sciences and humanities respectively. The study also employed the simple random sampling techniques of the balloting type to identify 844 lecturers $(10 \%$ of the population). Data collected was analysed using descriptive statistics which involves frequency counts and simple percentages. 


\section{RESULT}

\section{Demographic representation of the respondents}

Table: 1 Questionnaire distribution and response rate

\begin{tabular}{|l|l|l|l|}
\hline Universities used in the study & $\begin{array}{l}\text { Number } \\
\text { administered }\end{array}$ & $\begin{array}{l}\text { Number } \\
\text { returned }\end{array}$ & $\begin{array}{l}\text { Percentage rate } \\
\text { of response }\end{array}$ \\
\hline University of Nigeria Nsukka (UNN) & 150 & $141(94 \%)$ & 18.8 \\
\hline Federal University, Oye-Ekiti (FUOYE) & 83 & $78(94)$ & 10.4 \\
\hline Federal University of Technology, Akure, (FUTA) & 68 & $43(63 \%)$ & 5.7 \\
\hline University of Jos (UNIJOS) & 130 & $126(97 \%)$ & 16.8 \\
\hline Ahmadu-Bello University (ABU) & 168 & $160(93 \%)$ & 21.3 \\
\hline Obafemi Awolowo University (O A U) & 110 & $56(51 \%)$ & 7.5 \\
\hline University of Ibadan (UI) & 154 & $104(68 \%)$ & 13.9 \\
\hline Covenant University (CU) & 43 & $43(100 \%)$ & 5.6 \\
\hline Total & 906 & 751 & 100 \\
\hline
\end{tabular}

Table 1 reveals the distribution of respondents by their rate of returns of the questionnaire from the Universities. The table reveals that out of 906 copies of the questionnaire administered to the respondents in the eight universities, 751 copies of the research instruments were adequately filled and returned, giving a response rate of $83 \%$. The table shows that the highest number of the participants was from Ahmadu-Bello University with 168 copies of questionnaire distributed and 160 copies returned. This is followed by UNN where 150 questionnaire copies were administered and 141 copies were returned. In University of Jos 130 copies of the questionnaire were distributed and 122 were returned. At University of Ibadan 154 copies of the questionnaire were distributed and 104 copies were returned. 83 copies of the research instruments were administered at the Federal University, Oye-Ekiti and 78 copies were returned. A total of 110 copies of the questionnaire were administered in Obafemi Awolowo University and 56 copies were returned, while in Federal University of Technology, Akure, Ondo State 68 copies of the questionnaire were distributed, and only 43 copies of the questionnaire were returned, while Covenant University had the highest return rate of questionnaire, 43 copies of the questionnaire were administered and all the 43 questionnaire copies were returned. Table 1 above also revealed that FUTA and Covenant universities had the least percentage of representation due to their sparse population in terms of academic staff while ABU, UNN, Jos and UI, ranked the highest in population and representation for the study. 
Table: 3 Distribution of respondents by Faculty

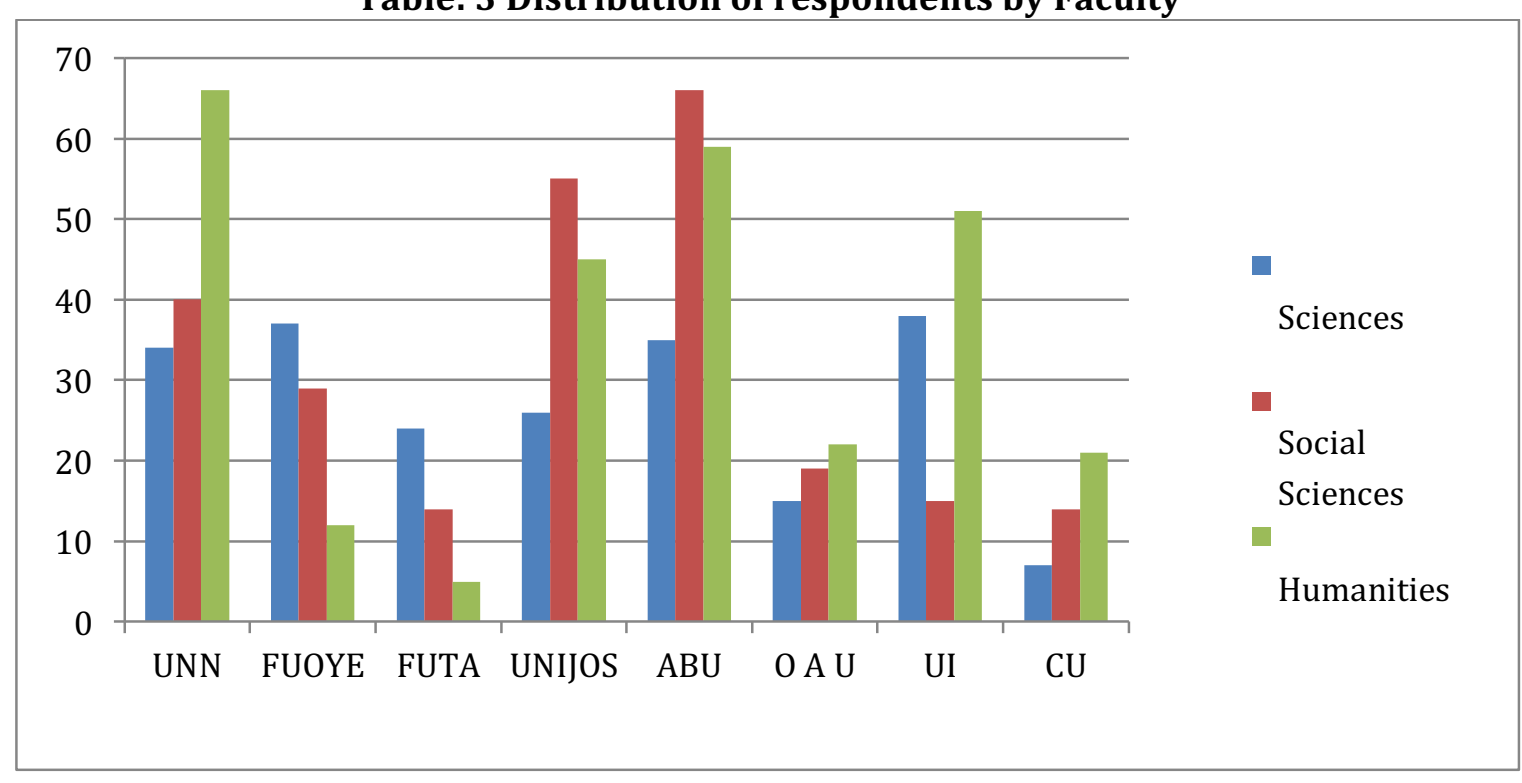

Figure 1: Distribution of respondents by Faculty

Figure 1 reveals that among the faculties used in the study, lecturers from the faculties of the Humanities were more 281(37.4\%), followed by those in the Social Sciences 253(33.7\%), and then Sciences 217(28.9\%). Humanities 281(37.4\%) has more participant, with 66 from University of Nigerian (UNN), 59 from Amadu-Bello University (ABU), 45 from University of Jos (UNIJOS), 45 from University of Ibadan (UI), 12 from Federal University, Oye-Ekiti (FUOYE) , 22 from Obafemi Awolowo University (OAU), 5 respondents from Federal University of Technology, Akure (FUTA), and 21 respondents from Covenant University (CU). For social science, ABU has 66 sampled respondents; UNIJOS has 55 respondents and UNN has 40 respondents. While for the science, UI has 37 respondents, FUOYE 37, ABU has 35 respondents; UNN 34 respondents and 26 respondents were from FUOYE. Therefore, more of the respondents that participated in the study were from humanities, followed by those from social science and then those from science department.

Table 2 presents the copyright related issues affecting institutional repositories in university libraries in Nigeria. 
Table 2: Copyright related issues affecting institutional repositories in university libraries in Nigeria

\begin{tabular}{|c|c|c|c|c|}
\hline Statement & 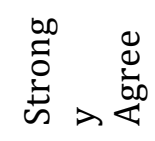 & 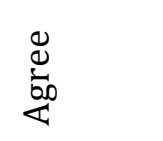 & 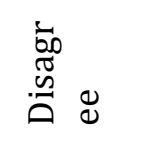 & 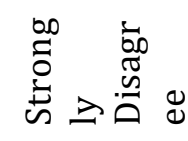 \\
\hline $\begin{array}{l}\text { Copyright and intellectual property is a concern for } \\
\text { researchers in the use of IR in universities in Nigeria. }\end{array}$ & $\begin{array}{l}360 \\
(49.2 \%)\end{array}$ & $\begin{array}{l}281 \\
(38.4 \%)\end{array}$ & $\begin{array}{l}63 \\
(8.6 \%)\end{array}$ & $\begin{array}{l}27 \\
(3.7 \%)\end{array}$ \\
\hline $\begin{array}{l}\text { Copyright is regularly being violated through plagiarism } \\
\text { in universities in Nigeria. }\end{array}$ & $\begin{array}{l}229 \\
(31.4 \%)\end{array}$ & $\begin{array}{l}338 \\
(46.4 \%)\end{array}$ & $\begin{array}{l}120 \\
(16.5 \%)\end{array}$ & $\begin{array}{l}42 \\
(5.6 \%)\end{array}$ \\
\hline $\begin{array}{l}\text { Copyright is regularly being violated through piracy and } \\
\text { photocopying in Nigeria }\end{array}$ & $\begin{array}{l}250 \\
(34.2 \%)\end{array}$ & $\begin{array}{l}289 \\
(39.6 \%)\end{array}$ & $\begin{array}{l}143 \\
(19.6 \%)\end{array}$ & $\begin{array}{l}48 \\
(6.6 \%)\end{array}$ \\
\hline $\begin{array}{l}\text { Counterfeiting are fears of academics in the use of IR in } \\
\text { universities in Nigeria. }\end{array}$ & $\begin{array}{l}241 \\
(33.0 \%)\end{array}$ & $\begin{array}{l}326 \\
(44.7 \%)\end{array}$ & $\begin{array}{l}121 \\
(16.6 \%)\end{array}$ & $\begin{array}{l}42 \\
(5.8 \%)\end{array}$ \\
\hline $\begin{array}{l}\text { There is no workable policy guiding copyright matters } \\
\text { and its implementations in Nigeria }\end{array}$ & $\begin{array}{l}210 \\
(28.8 \%)\end{array}$ & $\begin{array}{l}323 \\
(44.3 \%)\end{array}$ & $\begin{array}{l}137 \\
(18.8 \%)\end{array}$ & $\begin{array}{l}58 \\
(8.0 \%)\end{array}$ \\
\hline $\begin{array}{l}\text { There is no functioning commission to monitor and } \\
\text { regulate copyright issues in the universities in Nigeria }\end{array}$ & $\begin{array}{l}243 \\
(33.5 \%)\end{array}$ & $\begin{array}{l}339 \\
(46.8 \%)\end{array}$ & $\begin{array}{l}108 \\
(14.9 \%)\end{array}$ & 35 \\
\hline Copyright laws in Nigeria are not very clearly spelt out & $\begin{array}{l}206 \\
(28.4 \%)\end{array}$ & $\begin{array}{l}346 \\
(47.7 \%)\end{array}$ & $\begin{array}{l}122 \\
(16.8 \%) \\
\end{array}$ & $\begin{array}{l}52 \\
(7.2 \%)\end{array}$ \\
\hline Copyright laws are not usually enforced in Nigeria & $\begin{array}{l}188 \\
(25.9 \%)\end{array}$ & $\begin{array}{l}338 \\
(46.6 \%)\end{array}$ & $\begin{array}{l}152 \\
(21.0 \%)\end{array}$ & $\begin{array}{l}47 \\
(6.5 \%)\end{array}$ \\
\hline $\begin{array}{l}\text { Publishers Contract Policy that mandates authors to } \\
\text { give away their copyright to publishers in order to get } \\
\text { their works published is a limitation to lecturers' } \\
\text { submission of their work to IR. }\end{array}$ & $\begin{array}{l}187 \\
(25.9 \%)\end{array}$ & $\begin{array}{l}328 \\
(45.4 \%)\end{array}$ & \begin{tabular}{|l|l|}
160 \\
$(22.2 \%)$
\end{tabular} & $\begin{array}{l}47 \\
(6.5 \%)\end{array}$ \\
\hline
\end{tabular}

Table 2 reveals the various copyright related issues affecting institutional repositories in university libraries in Nigeria. The table ascertained that there are copyright related issues contending with IRs in university libraries in Nigeria, and these are concerns for academics/researchers. Most of the respondents (87.6\%) agreed that, copyright and intellectual property is a concern for researchers in the use of IRs. $78 \%$ of the respondents agreed that copyright is regularly being violated through plagiarism in universities in Nigeria. Whereas, $74 \%$ and $78 \%$ of the respondents respectively opined that copyright is also regularly being violated through piracy and photocopying. Again, 74\% of the respondents were of the view that counterfeiting are fears of academics in the use of IR in universities in Nigeria, while $73.1 \%$ ascertained that there is a non workable policy guiding copyright matters and its implementations in Nigeria, coupled with non functioning commission to monitor and regulate copyright issues. The result further reveals that, $76 \%$ of the respondents opined that the Nigerian copyright laws are not very clear, and $72.5 \%$ ascertained that copyright laws are not usually enforced. Again, 71.3\% agreed that Publishers Contract Policy that mandates authors to give away their copyright to publishers in order to get their works published is a limitation.

\section{Solutions to the issues of copyright in institutional repositories in university libraries in Nigeria.}

The Lecturers' responses in the open-ended questions of the questionnaire suggested that structures should be put in place for the enforcement of copyright laws, and a system of levy for every photocopy made in the country for the benefit of the authors in the countries, just like in the developed countries. Some other suggestions to the issues of copyright by the lecturers are: 
- Proper sensitization and Awareness campaigns: There should be proper and adequate awareness campaigns and sensitization of the universities community and their environments on IRs and copyright matters through different media e.g. universities websites, fliers, posters, social media and workshops.

- The authors need to be educated on their intellectual property right, and they should remain the owners of the copyright of their works and not their institutions or publishers.

- There should be structures for the implementation of a workable national policy guiding copyright matters to secure intellectual properties.

- Penalizing offenders: Lecturers were of the opinion that copyright laws need to be enforced to the later without respect for persons. This is because if people know that they cannot get away with infringement on copyright, they will be restrained in the use of other people's work.

- Thorough monitoring: For the copyright laws to be enforced effectively there is need for thorough monitoring in order to dictate the culprits. This can be ensured by establishing a functioning commission to monitor and regulate copyright issues within each of the universities in Nigeria.

- Dealing with poverty and liaising with copiers so that only copyright approved works are copied. The problem of poverty has a cyclic effect on the society. This is so due to the fact that when people cannot afford the basic necessities of life, they might begin to get indulged in unethical and fraudulent behaviors. The government and the citizens of Nigeria need to establish and maintain structures that will boast the national economy and fight unemployment.

\section{DISCUSSION AND CONCLUSION}

The copyright related issues affecting institutional repositories in university libraries in Nigeria are: plagiarism, piracy, counterfeiting, photocopying; lack of non workable policy guiding copyright matters and its implementations coupled with Publishers Contract Policy that mandates authors to give away their copyright to publishers in order to get their works published. Though copyright laws do exist in Nigeria, they are not very clearly spelt out and enforced in Nigeria like in advanced countries. As a result of that, many people do so many fraudulent things with other people's work and get away with it in Nigeria. Literature confirmed that the rate of copyright violation in Nigerian tertiary institutions is quiet dismal. Reprography is the major way in which the various activities amounting to violation or infringement of copyright such as plagiarism, counterfeiting and piracy are realised (Egonwa, 2005). Igbeneghu (1993) collaborated this by affirming that a huge photocopying activities and violation of copyright in Nigerian universities is ongoing. This has implications on the establishment and sustenance of IRs in Nigeria as the lecturers who are the key stake holders are reluctant to submit their works into the repositories.

In the developed countries there is an existing structure fixed for the enforcement of copyright laws, and a system of levy for every photocopy made in these countries for the benefit of the authors, this structure should be adopted in Nigeria as well. A proper scale should be worked out for universities to pay for the volumes in their library holdings to make up for photocopying by staff and students. That means suggesting to these institutions to take charge of the photocopying by staff and students, as it is the case in most advanced countries of the world. 


\section{Conclusion}

Copyright violation is the major fear of academics in the submission of their works to IRs. To eliminate the copyright problems of IR, there is need for proper sensitization and awareness campaigns on copyright matters within the universities and the environment. Thorough monitoring and appropriate structures should be put in place for the enforcement of copyright laws. The government and the universities' management need to constitute a national workable policy guiding copyright matters and IRs, as it is certain that no one would like to throw his achievements to the public without adequate security.

\section{References}

Abrizah, A. (2009). The cautious faculty: Their awareness and attitudes towards institutional repositories. Malaysian Journal of library and Information Science, 14(2), 17-37.

Allen, J. (2005). Interdisciplinary differences in attitudes towards deposit in institutional repositories. (Master's thesis, Manchester Metropolitan University). Retrieved from http://eprints.rclis.org/archive/00005180/01/FULLTEXT.pdf

Association of Research Libraries. (2006). Institutional repositories: SPEC Kit 292. Washington, DC: Association of Research Libraries.

Casey, A. M. (2012). Does Tenure Matter? Factors Influencing Faculty Contributions to Institutional Repositories. Journal of Librarianship and Scholarly Communication 1(1):eP1032.

Chan, L. (2004). Supporting and enhancing scholarship in the digital age: the role of open-access institutional repositories. Canadian Journal of Communication, 29, 277-300.

Crow, R. (2002). The case for institutional repositories: A SPARC position paper. Washington, DC: Scholarly Publishing and Academic Resources Coalition. Retrieved from http://www.arl.org/sparc/bm doc/ir_final_release_102.pdf

Cullen, R. and Chawner, B. (2011). Institutional repositories, open access, and scholarly communication: A study of conflicting paradigms. The Journal of Academic Librarianship, 37(6), 460-470.

Davis, P. M. and Connolly, M. J. L. (2007). Institutional repositories: Evaluating the reasons for non-use of Cornell University's installation of DSpace. D-Lib Magazine, 13(3/4).

Dolan, M. (2011). Assessing awareness of repositories and the open access movement among ETD faculty advisors. Available:

Egonwa, O.D 2005. Copyright in Nigeria's tertiary institutions. Paper presented at the $4^{\text {th }}$ Nigeria International Book fair on Publishing in indigenous languages.

Eke, H. N. 2011. Digitizing resources for University of Nigeria repository: Process and Challenges. Webology, $8(1)$

Ekpo, M.F 1998. The Copyright Climate in Nigeria: Issues for Authors Action in Nigeria. Lagos. Alfa Communications Ltd.

Foster, N. F., and Gibbons, S. (2005). Understanding faculty to improve content recruitment for institutional repositories. D-Lib Magazine, 11(1). doi:10.1045/january2005-foster

http://dl.cs.uct.ac.za/conferences/etd2011/papers/etd2011_dolan.pdf

Jackman, S. Y. (2007) Creating an IR at the University of Liverpool: Our approach. SCONUL Focus vol. 42, pp. 35 37

Jantz, R. C. and Wilson, M. Y. (2008). Institutional repositories: Faculty deposits, marketing, and the reform of scholarly communication. The Journal of Academic Librarianship, 34(3), 186-195.

Jantz, R. C., and Wilson, M. Y. (2008). Institutional repositories: Faculty deposits, marketing, and the reform of scholarly communication. The Journal of Academic Librarianship, 34(3), 186-195.

Johnson, R. K. (2002). Institutional Repositories: Partnering with Faculty to Enhance Scholarly Communication. $D$ Lib Magazine, 8:11.

Kim, J. (2007). Motivating and impeding factors affecting faculty contribution to institutional repositories. Journal of Digital Information, 8(2). Retrieved from http://journals.tdl.org/jodi/article/viewArticle/193/177. 
Lynch, C. A., and Lippincott, J. K. Institutional repository deployment in the United States as of early 2005. D-Lib Magazine, 11, 9, 2005. http://www.dlib.org/dlib/september05/lynch/09lynch.html

Manjunatha, K. and Thandavamoorthy, K. (2001). A study on researchers' attitude towards depositing in institutional repositories of universities in karnataka (India). International Journal of Library and Information Science, 3(6): 107-115.

Nicholas, D., Rowlands, I., Watkinson, A., Brown, D., and Jamali, H. R. (2012). Digital repositories ten years on: What do scientific researchers think of them and how do they use them? Learned Publishing, 25 (3), $195-206$.

Okwilagwe A.O. (2001) Book Publishing in Nigeria; pg 143-178

Pelizzari, E. (2005). Harvesting for disseminating: open archives and the role of academic libraries. The Acquisitions Librarian, 33/34, 35-51.

Prosser, D. C. (2003) Scholarly communication in the 21st century - the impact of new technologies and models. Serials. 16(2), 163-167.

Rowlands, I., Nicholas, D. and Huntington, P. (2004). Scholarly communication in the digital environment: What do authors want? Learned Publishing, 17(4), 261-73.

Schonfeld, R. C., and Houseright, R. (2010). Faculty survey 2009: Key strategic insights for libraries, publishers, and society. Retrieved from http://www.ithaka.org/ithaka-s-r/research/facultysurveys-20002009/Faculty\%20Study\%202009.pdf

Shearer, M. K. (2003). Institutional repositories: towards the identification of critical success factors. The Canadian Journal of Information and Library Science, 27, 3, 89-108.

Ware, M. (2004). Institutional repository and scholarly publishing. Learned publishing, 17, 115-124. 